\title{
THE TARGETING OF ZERO-RATED BASIC FOODSTUFFS UNDER VALUE-ADDED TAX (VAT) IN SOUTH AFRICA
}

\author{
A Jansen, E Stoltz and D Yu*
}

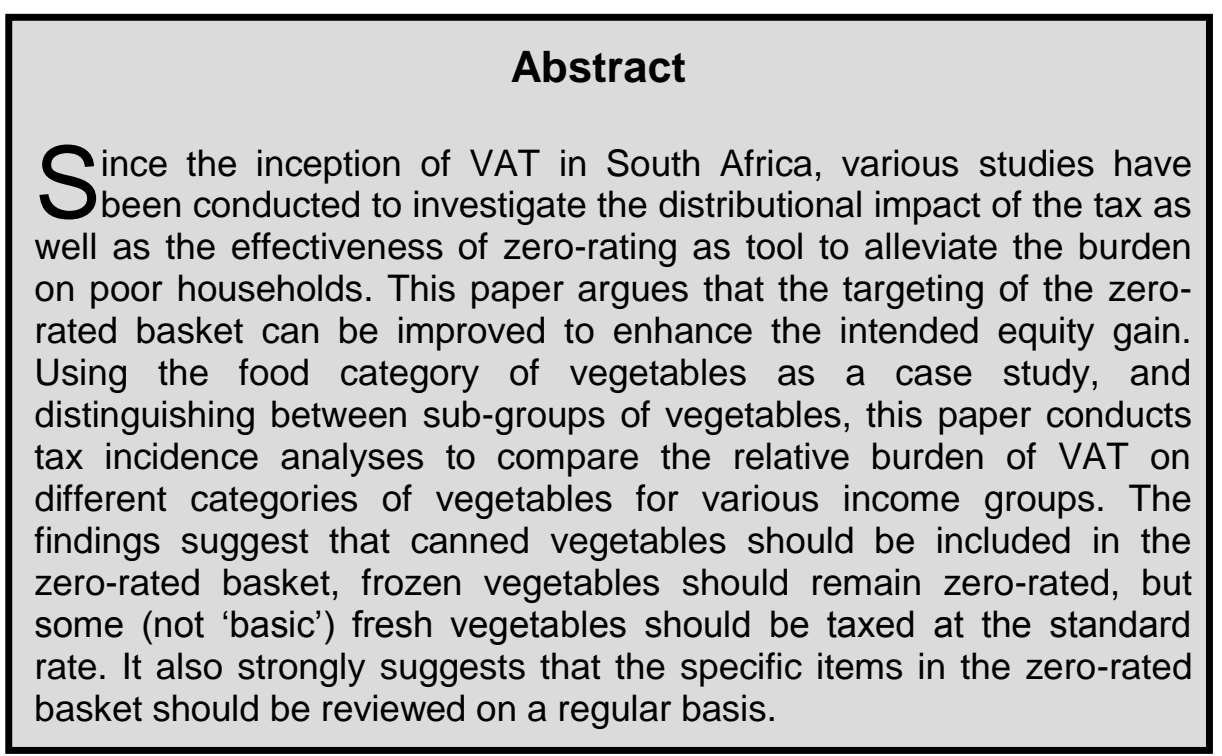

\section{Introduction}

Value-added tax (VAT) is at present the second most important source of government revenue in South Africa, but as in most countries around the world, its impact on income distribution is controversial. Given the country's political history and the extremely skewed distribution of income and wealth, the impact of the tax is even more controversial in South Africa. The mere fact that the rate has been unchanged at $14 \%$ since 1993 indicates that VAT is a politically sensitive tax handle, which is clear from the strong resistance over the years by the Congress of South African Trade Unions (COSATU) against any suggestions to increase the standard rate.

Since the inception of the first broad-based indirect tax in South Africa in 1978, which was replaced with VAT in 1991, the economic incidence of the tax on poor households was a politically sensitive and controversial issue. For this reason, zero-

\footnotetext{
* First author from Department of Economics, Stellenbosch University, Private Bag X1, Matieland 7602. Second and third author from Department of Economics, University of the Western Cape, Private Bag X17, Bellville 7535, Republic of South Africa.

Email: dyu@uwc.ac.za
} 
rating of basic foodstuffs is used to mitigate the regressive impact. Over the years various studies (to be discussed in Section 2), some commissioned by the South African government, investigated the redistributive consequences of the tax and confirmed its regressive impact. Subsequently some additional foodstuffs were zero-rated. However, despite the zero-rating of basic foodstuffs, the impact of the tax is still regressive which can partly be ascribed to the relatively high rate on food, worsening the position of poor households (Gillingham, 2008:50). Furthermore, a specific recommendation by the Katz Commission (1994) that the zero-rated basket should be regularly reviewed has not been implemented.

This paper addresses the question of whether the current basket of zero-rated basic foodstuffs is efficiently targeted. It is certainly not an easy task to target the poor effectively, given that expenditure patterns are intricate and change over time. The distributional impact of a single tax should also not be judged in isolation; it is the equity impact of the whole tax system that is important. Furthermore, it is total fiscal incidence that really matters and the expenditure side of the national budget is generally regarded as a more efficient instrument to cater for the needs of the poor. However, this paper argues that the targeting of the zero-rated basket can be improved to enhance the possible equity gain. It also reiterates the recommendation by the Katz Commission (1994), which is supported by Cnossen (2003), that the zero-rated basket should be systematically reviewed on a regular basis.

Using the food category of vegetables as a case study, the paper suggests that minor changes to the tax treatment of sub-categories could enhance the equity gain from zero-rating. The first part of the paper focuses on the findings of various studies over the years on the distributional impact of the tax in South Africa. This is followed by some descriptive statistics illustrating the most recent household expenditure patterns on vegetables across income groups. Thereafter, using a partial equilibrium approach to tax incidence analyses, the distributional impact of VAT on different categories of vegetables is determined in an attempt to motivate the proposed changes to the zero-rated basket of basic foodstuffs. The final section offers a conclusion and makes some recommendations.

\section{The quest to make VAT less regressive in South Africa}

Since the introduction of the General Sales Tax (GST) the distributional consequences of the first broad-based sales tax remained under scrutiny, especially by COSATU. This culminated in the first zero-rating of basic foodstuffs on 1 July 1984 (Stoltz, 1987: 95-96). However, Tait (1985: 2) ${ }^{1}$ claimed that "the food exclusion to GST does not ameliorate the regressivity of the tax by as much as might be expected." He blamed this on the specific classification of the types of foodstuffs that were targeted. Stoltz (1987: 96) cited the examples of dried beans, canned food and vegetable oil, products which were not zero-rated, despite being generally regarded as staple food for the poor.

\footnotetext{
${ }^{1}$ Alan Tait was a tax authority from the Fiscal Affairs Department of the IMF who at the time acted as technical advisor to the Margo Commission.
} 
Smit (1986), in an unpublished study for the Margo Commission, used a social accounting matrix and estimated the tax burden of direct as well as indirect taxes for 1985 (Fourie and Owen, 1993). He based his calculations on a GST rate of 12\% and found that the burden of this tax ranged "from approximately 8,5\% of per capita household income for the poorest groups to approximately $4,5 \%$ for the richest groups" (Fourie and Owen, 1993: 286). This clearly indicates the regressive impact of the tax.

In September 1991 a consumption-type of value-added tax (VAT) was introduced at a rate of $10 \%$ to replace GST, mainly for its revenue-raising potential and selfpolicing features. ${ }^{2}$ In 1993 the rate was increased to $14 \%$. Right from the start there were concerns about the regressive impact of the tax and as a result additional selected basic foodstuffs, such as maize meal, milk, fruit and vegetables as well as paraffin, have been zero-rated since then. ${ }^{3}$ As mentioned earlier, various studies in subsequent years focused on the distributional impact of the tax and on zero-rating as policy tool. The following paragraphs present the main findings of some of the studies chronologically.

Fourie and Owen (1993: 289) confirmed the regressive impact of VAT in South Africa. They found that the VAT burden declined from 7,6\% of total household income ${ }^{4}$ for the poor to $4,3 \%$ for the rich (inclusive of zero-rating). However, they claimed that zero-rating ameliorated the VAT burden on the poor significantly (1993:290). They determined that only one third of the total revenue loss as a result of zero-rating went to households from the poorest three income groups (out of nine groups identified). Although the rich logically gained more in absolute terms, it is the relative gain from zero-rating which really matters when the regressive impact is considered. Fourie and Owen (1993: 283) furthermore warned: "An increased reliance on such a tax could have significant implications for economic justice and poverty, with obvious political ramifications."

The Katz Commission commented in its First Interim Report (1994:122-123) on the possibility of introducing a higher VAT rate on selected luxury goods to mitigate the regressive impact of the tax, but then found that the effect would be negligible. The Commission claimed that a comprehensive basket of luxury goods and also much higher rates would be required to achieve a meaningful reduction in regressivity. The Commission therefore rejected the introduction of a higher VAT rate on luxury goods, and recommended that targeted poverty relief should be

\footnotetext{
2 The GST system suffered from serious evasion, since all tax was collected at the end of the distribution chain.

3 Cnossen (2003:6) gives a complete list of the zero-rated food items: "brown bread, maize meal, samp, mealie rice, dried mealies, dried beans, lentils, pilchards/sardinella in tins, milk powder, dairy powder blend, rice, vegetables, fruit, vegetable oil, milk, cultured milk, brown wheaten meal, eggs, edible legumes and pulses of leguminous plants." In addition, illuminated paraffin was added to the list of zero-rated items in 2001 (Republic of South Africa, 2001).

4 Although the tax burden can be measured as percentage of income or consumption, this paper follows the example of Fourie and Owen (1993) as well as Cnossen (2003) and measures the burden against income.
} 
considered instead. It is significant for the purpose of this paper that the Katz Commission (1994: 123) claimed that "it might be possible, based on equity considerations, to improve on the present basket of zero-rated goods" and also recommended that "the revenue authorities should from time to time systematically review the current basket of zero-rated goods, with reference, inter alia, to the distributional aspects."

Cnossen (2003) investigated the incidence of consumption taxes in SADC countries. Whilst acknowledging that rate and base differentiation ${ }^{5}$ was a widely used approach to mitigate the regressive impact of VAT in developing countries, he explicitly referred to it as a second-best instrument. He also referred to the fact that the relative position of the poorest households would not improve should changes to the income tax structure be used to address equity concerns and then stated: "Accordingly, there is a residual case for exemption or applying a lower rate to foodstuffs" (Cnossen, 2003:12). What is particularly relevant for this paper is his statement that the "efficacy of rate- and base-differentiated" consumption taxes should be examined at regular intervals (Cnossen, 2003:3), which supports the recommendation by the Katz Commission referred to earlier.

Go, Kearny, Robinson and Thierfelder (2005) used a computable general equilibrium (CGE) model to determine the distributional implications of possible reforms to VAT in South Africa. They explained that there was room for changes to the VAT system that would make the incidence of the tax less regressive and explicitly stated (2005:19): "Minor changes to the tax structure can have a substantial impact on the tax burden for low-income households." Go et al. (2005) also confirmed the earlier results by Fourie and Owen (1993) regarding the regressive impact of VAT and mentioned that this was the case notwithstanding the zero-rating of basic foodstuffs. Go et al. (2005: 6) also claimed that the intended benefit from the zero-rating of paraffin in 2001 had been absorbed by suppliers and not passed on to consumers.

Price Waterhouse Coopers (2007) was commissioned by the National Treasury to investigate zero-rating specific merit goods, such as education and health services. Part of the directive was to determine the possible impact of the zero-rating of individual items, such as specific types of meat and fruit (oranges). The findings of this study were presented at a National Tax Symposium in 2008, but unfortunately have not been made available. An unofficial discussion (12 July 2009) with a senior office-bearer of the firm revealed that the recommendations of the report were not considered by the National Treasury because of an explicit policy decision at that time against any further zero-rating (in order to protect the tax base). ${ }^{6}$ In addition, he mentioned that the South African canned fruit and vegetable industry was also

\footnotetext{
5 Studies often use the terms exemption and zero-rating interchangeably. Cnossen (2003:13) prefers the term 'exemption' to 'zero-rating', because he believes it would be "greater deterrent to political pressures to increase the number of favoured products."

${ }^{6}$ Ensor (2008) reported that chicken, sorghum products and baby products were some of the items under consideration for possible additional zero-rating. The government, however, soon afterwards rejected this possibility (claiming that the rich would gain substantially more from zero-rating than the poor).
} 
putting pressure on government to zero-rate canned foodstuffs. This is significant for the purpose of this paper.

It therefore came as no surprise when the Minister of Finance made it clear in the 2008 Medium Term Budget Policy Statement (Republic of South Africa, 2008:42) that despite pressure, no further foodstuffs would be zero-rated and explicitly stated: "Evidence suggests that existing VAT zero-ratings and exemptions in almost all cases confer substantially more benefits on middle- and higher-income groups than on lower-income groups". ${ }^{7}$ It is particularly this statement that this paper is investigating by focusing on the meaning of "substantially more benefits". Whilst it is obvious that higher-income groups gain more from zero-rating in absolute terms because they spend larger amounts, poorer households gain more in relative terms. This statement by the government therefore is in contrast to the findings of Fourie and Owen (1993) as well as the statement by Cnossen (2003) regarding the efficacy of zero-rating in mitigating the regressive impact of VAT.

Moreover, in the recent past and over various budget years the South African government has significantly reduced the tax burden on low and middle incomeearners through changes to the individual income tax structure. ${ }^{8}$ These efforts exacerbated the real and perceived inequity of the tax system, as they did not reach the poorest of households who are not liable for income tax. It is noteworthy that Fourie and Owen (1993:283) referred to Bird (1992), who opposed the argument that regressivity can be effectively addressed by changes to the income tax structure. Cnossen (2003:12) also agreed that it "does not help the really poor."

Despite efficiency arguments against the narrowing of the VAT base through exemptions and zero-rating, it is not a policy that will easily disappear. Bird (2008:12) claims that since fairness is a key principle of tax design, policy makers may regard zero-rating as a worthwhile exercise, despite the loss of revenue. Fourie and Owen (1993:284) mentioned that recommendations to reduce or eliminate zero-rating were rarely followed in practice and stated that, apart from the fact that it would not be politically responsible in the South African context, they could not be implemented as long as the social security system was not optimal. This argument still holds as Van der Berg (2009), in a study on the fiscal incidence of social spending in 2006, indicates that even though social spending on the poor has increased, it can only have a limited impact in addressing the high degree of inequality. Fourie and Owen (1993:284) referred to Aaron (1981), who stated that "political and social pressures make a pure system impossible in practice." It can therefore be expected that zero-rating of VAT will remain part and parcel of the structure of VAT in South Africa.

\footnotetext{
7 The minister also claimed that "producers and suppliers may capture a large percentage of the benefit of VAT zero-rating" (Republic of South Africa, 2008). This statement proves that the government was aware of the concerns raised by Alderman and Del Ninno (1999), COSATU (1999) and Calcaterra and Kirsten (2003).

8 The South African government granted income tax relief of R63 417 million over the budget years 2004-05 to 2009-10 (National Treasury \& South African Revenue Service, 2010). None of this reached the really poor.
} 
However, certain anomalies are part of the present system of zero-rating. A particular case in point is the category of vegetables, which can be broken down into different sub-categories. Canned vegetables, mostly consumed by relatively poorer households, are not included in the zero-rated basket. In contrast, relatively luxurious unprocessed fresh vegetables (for example, asparagus and mushrooms) are mostly consumed by relatively richer households, but are zero-rated. The next section presents a case study on the tax treatment of specific sub-categories of vegetables as an example of changes that can be made to the zero-rated basket of basic foodstuffs, which may enhance the equity gain from this costly exercise (in terms of loss of tax revenue).

\section{Case study on the tax treatment of the food category of vegetables}

This section commences with a brief discussion on the selection of basic foodstuffs, which is followed by an explanation of the data used in the subsequent analyses. After that, expenditure patterns of various income groups for different subcategories of vegetables are investigated. Finally, the tax incidence analyses focus on the equity impact of VAT imposed on these sub-categories.

\subsection{Selecting basic foodstuffs for zero-rating}

It is not easy to select which basic foodstuffs should be considered for possible zero-rating from VAT (Fourie and Owen, 1993). According to Cnossen (1991:81), the definition of essential goods tends to differ between countries. For example, Tait (1988: 59-60) distinguished between essential and luxury foods, assuming that luxury food items will be unaffordable to poorer households. He explained that it often required a distinction between processed and unprocessed foodstuffs. Calcaterra and Kirsten (2003:2), on the other hand, distinguish between basic foods, referring to products that undergo minimal processing, and staple foods, which are traditionally linked to the diets of poor households. Fourie and Owen (1993), in their analyses of VAT, considered whether goods are disproportionately consumed by the poor, and whether the spending on these goods is a crucial share of their household budget.

Given that equity is the main concern, it stands to reason that the equity gain to the poor should be maximised. This study follows the example of Fourie and Owen (1993) and focuses on products that are disproportionally consumed by the poorest households. It also considers the zero-rating of sub-categories of food items, particularly where the spending patterns between the poor and rich are distinctly different (an approach suggested by Cnossen (2003)).

\subsection{Data and analyses}

Data from the Income and Expenditure Survey 2005/2006 (IES 2005/2006), as released by Statistics South Africa (2008), are used. These data include comprehensive information on expenditure patterns of households throughout the country. Households are divided into Quintiles, ranging from the poorest 20\% of 
households (Quintile1) to the richest 20\% (Quintile5), based on per capita income in constant (2000) prices.

The analyses have three components. Firstly, household spending patterns on different sub-categories of vegetables are analysed to determine which types of vegetables are consumed disproportionately by the poorest households. Secondly, a partial equilibrium approach is used to determine the incidence of VAT between income groups for different sub-categories of vegetables. In addition, following Fourie and Owen (1993), weighted equity gain ratios are derived to support the earlier analysis.

\subsection{Spending on vegetables}

This section focuses on spending patterns on vegetables of households across the income distribution spectrum in South Africa. Table 1 shows that Quintile 1 spent the smallest amount (in absolute terms) on vegetables as compared to Quintile 5. Vegetable spending as a percentage of the food budget ranges from as low as 9,3\% in Quintile 4 and Quintile 5 to as high as $12,76 \%$ in Quintile 1 . This clearly implies that vegetables are important in the food baskets of poorer households.

Vegetable spending as a percentage of household income is the highest for Quintile $1(7.66 \%)$ compared to Quintile $5(0.50 \%)$. This once again shows that vegetables are relatively more important for poorer households and may explain the inclusion of some of the sub-categories in the zero-rated basket.

Table 1: Household spending on vegetables

\begin{tabular}{l|c|c|c}
\hline Category & $\begin{array}{c}\text { Total annual spending } \\
\text { on vegetables } \\
\text { (R million) }\end{array}$ & $\begin{array}{c}\text { Total annual spending } \\
\text { on vegetables as a \% of } \\
\text { total food spending }\end{array}$ & $\begin{array}{c}\text { Total annual spending } \\
\text { on vegetables as a \% of } \\
\text { total income }\end{array}$ \\
\hline Quintile 1 & 1356 & $12,76 \%$ & $7,66 \%$ \\
\hline Quintile 2 & 1322 & $11,07 \%$ & $3,87 \%$ \\
\hline Quintile 3 & 1222 & $10,11 \%$ & $2,27 \%$ \\
\hline Quintile 4 & 1276 & $9,32 \%$ & $1,22 \%$ \\
\hline Quintile 5 & 2131 & $9,36 \%$ & $0,50 \%$ \\
\hline \multicolumn{2}{l}{ Source: Own calculations. Data from IES 2005/2006, Statistics South Africa, 2008 }
\end{tabular}

A more detailed analysis of different sub-categories of vegetables, however, shows varying spending patterns between poor and rich households. Vegetables are subdivided into the following sub-categories: canned, frozen, 'basic' fresh and 'other' fresh vegetables. The IES 2005/2006 provides information on the spending patterns of households for 22 different types of fresh vegetables. Using spending patterns identified over income groups, it suggests that fresh vegetables can be sub-divided into two groups, namely a 'basic' category and an 'other' (more 'luxurious') category.

The definition of 'basic' fresh vegetables used here is based on spending patterns identified in Table 2, which shows the percentage of income spent on individual items of vegetables. If spending as a percentage of income on an individual item 
decreases across Quintiles, it is classified as a 'basic' item (see Table A.1 in the Appendix for the classification all vegetable items). If spending as a percentage of income increases across Quintiles, these items are classified as 'other' fresh vegetables. Although it would be more appropriate to refer to the 'other' fresh vegetables category as 'luxurious' fresh vegetables, the percentage spent on these items does not necessarily increase proportionally more than the income share. ${ }^{9}$

Table 3 illustrates the spending patterns (by Quintile) on each sub-category of vegetables as a percentage of income.

\section{Table 2: Spending on individual items of fresh vegetables}

\begin{tabular}{|c|c|c|c|c|c|c|c|c|c|c|}
\hline \multirow{2}{*}{ 'Basic' fresh vegetables } & \multicolumn{5}{|c|}{ Spending (Rand million) per Quintile } & \multicolumn{5}{|c|}{ Spending as percentage of income per Quintile } \\
\hline & $\begin{array}{c}\text { Quintile } \\
1\end{array}$ & $\begin{array}{c}\text { Quintile } \\
2\end{array}$ & $\begin{array}{c}\text { Quintile } \\
3\end{array}$ & $\begin{array}{c}\text { Quintile } \\
4\end{array}$ & $\begin{array}{c}\text { Quintile } \\
5\end{array}$ & $\begin{array}{c}\text { Quintile } \\
1\end{array}$ & $\begin{array}{c}\text { Quintile } \\
2\end{array}$ & $\begin{array}{c}\text { Quintile } \\
3\end{array}$ & $\begin{array}{c}\text { Quintile } \\
4\end{array}$ & $\begin{array}{c}\text { Quintile } \\
5\end{array}$ \\
\hline Fresh spinach/morogo & 100 & 44 & 27 & 25 & 25 & $0,567 \%$ & $0,128 \%$ & $0,050 \%$ & $0,024 \%$ & $0,006 \%$ \\
\hline Fresh cabbage & 134 & 120 & 84 & 58 & 31 & $0,757 \%$ & $0,351 \%$ & $0,156 \%$ & $0,056 \%$ & $0,007 \%$ \\
\hline Fresh green mealies & 41 & 27 & 12 & 5 & 10 & $0,233 \%$ & $0,078 \%$ & $0,022 \%$ & $0,005 \%$ & $0,002 \%$ \\
\hline Fresh tomatoes & 152 & 163 & 150 & 157 & 183 & $0,860 \%$ & $0,478 \%$ & $0,278 \%$ & $0,150 \%$ & $0,043 \%$ \\
\hline Fresh green beans & 6 & 5 & 6 & 10 & 21 & $0,033 \%$ & $0,014 \%$ & $0,011 \%$ & $0,010 \%$ & $0,005 \%$ \\
\hline Fresh pumpkin/butternut & 33 & 37 & 31 & 36 & 51 & $0,184 \%$ & $0,109 \%$ & $0,058 \%$ & $0,035 \%$ & $0,012 \%$ \\
\hline $\begin{array}{l}\text { Fresh green/red/yellow } \\
\text { pepper }\end{array}$ & 11 & 11 & 18 & 23 & 86 & $0,063 \%$ & $0,032 \%$ & $0,033 \%$ & $0,022 \%$ & $0,020 \%$ \\
\hline Fresh chillies & 1 & 1 & 2 & 3 & 5 & $0,007 \%$ & $0,004 \%$ & $0,004 \%$ & $0,003 \%$ & $0,001 \%$ \\
\hline Fresh mixed vegetables & 25 & 33 & 40 & 34 & 55 & $0,139 \%$ & $0,098 \%$ & $0,074 \%$ & $0,033 \%$ & $0,013 \%$ \\
\hline Onions & 88 & 96 & 96 & 104 & 103 & $0,499 \%$ & $0,282 \%$ & $0,178 \%$ & $0,100 \%$ & $0,024 \%$ \\
\hline Fresh carrots & 16 & 22 & 30 & 39 & 58 & $0,092 \%$ & $0,065 \%$ & $0,055 \%$ & $0,037 \%$ & $0,014 \%$ \\
\hline Beetroot & 13 & 18 & 18 & 17 & 15 & $0,074 \%$ & $0,053 \%$ & $0,034 \%$ & $0,016 \%$ & $0,004 \%$ \\
\hline Potatoes & 357 & 362 & 301 & 251 & 241 & $2,019 \%$ & $1,062 \%$ & $0,558 \%$ & $0,240 \%$ & $0,056 \%$ \\
\hline \multirow[t]{2}{*}{ Sweet potatoes } & 15 & 23 & 26 & 35 & 81 & $0,086 \%$ & $0,068 \%$ & $0,048 \%$ & $0,033 \%$ & $0,019 \%$ \\
\hline & 993 & 963 & 840 & 799 & 965 & $5,612 \%$ & $2,820 \%$ & $1,558 \%$ & $0,764 \%$ & $0,225 \%$ \\
\hline \multirow{2}{*}{ 'Other' fresh vegetables } & \multicolumn{5}{|c|}{ Spending (Rand million) per Quintile } & \multicolumn{5}{|c|}{ Spending as percentage of income per Quintile } \\
\hline & $\begin{array}{c}\text { Quintile } \\
1 \\
\end{array}$ & $\begin{array}{c}\text { Quintile } \\
2 \\
\end{array}$ & $\begin{array}{c}\text { Quintile } \\
3 \\
\end{array}$ & $\begin{array}{c}\text { Quintile } \\
4\end{array}$ & $\begin{array}{c}\text { Quintile } \\
5\end{array}$ & $\begin{array}{c}\text { Quintile } \\
1 \\
\end{array}$ & $\begin{array}{c}\text { Quintile } \\
2 \\
\end{array}$ & $\begin{array}{c}\text { Quintile } \\
3\end{array}$ & $\begin{array}{c}\text { Quintile } \\
4\end{array}$ & $\begin{array}{c}\text { Quintile } \\
5\end{array}$ \\
\hline Lettuce & 3 & 4 & 9 & 19 & 68 & $0,015 \%$ & $0,011 \%$ & $0,016 \%$ & $0,018 \%$ & $0,016 \%$ \\
\hline Fresh cauliflower & 1 & 2 & 1 & 5 & 18 & $0,006 \%$ & $0,006 \%$ & $0,003 \%$ & $0,005 \%$ & $0,004 \%$ \\
\hline Fresh broccoli & 0 & 0 & 1 & 2 & 24 & $0,001 \%$ & $0,001 \%$ & $0,003 \%$ & $0,002 \%$ & $0,006 \%$ \\
\hline Fresh marrow & 0 & 0 & 0 & 3 & 19 & $0,001 \%$ & $0,000 \%$ & $0,001 \%$ & $0,002 \%$ & $0,004 \%$ \\
\hline Fresh gem squashes & 1 & 1 & 3 & 5 & 21 & $0,007 \%$ & $0,003 \%$ & $0,006 \%$ & $0,005 \%$ & $0,005 \%$ \\
\hline Fresh cucumber & 2 & 2 & 5 & 15 & 57 & $0,010 \%$ & $0,006 \%$ & $0,009 \%$ & $0,014 \%$ & $0,013 \%$ \\
\hline Other fresh vegetables & 0 & 0 & 1 & 1 & 7 & $0,001 \%$ & $0,001 \%$ & $0,001 \%$ & $0,001 \%$ & $0,002 \%$ \\
\hline \multirow[t]{2}{*}{ Mushrooms } & 0 & 1 & 3 & 12 & 77 & $0,002 \%$ & $0,003 \%$ & $0,006 \%$ & $0,011 \%$ & $0,018 \%$ \\
\hline & 8 & 11 & 24 & 61 & 291 & $0,044 \%$ & $0,031 \%$ & $0,045 \%$ & $0,058 \%$ & $0,068 \%$ \\
\hline
\end{tabular}

\footnotetext{
9 According to the definition of luxury goods, spending should increase proportionally more than income (Nicholson, 1998).
} 
Table 3: Spending on each sub-category of vegetable items as percentage of income

\begin{tabular}{c|c|c|c|c}
\hline Category & $\begin{array}{c}\text { Canned } \\
\text { vegetables }\end{array}$ & $\begin{array}{c}\text { Frozen } \\
\text { vegetables }\end{array}$ & $\begin{array}{c}\text { 'Basic' fresh } \\
\text { vegetables }\end{array}$ & $\begin{array}{c}\text { 'Other' fresh } \\
\text { vegetables }\end{array}$ \\
\hline Quintile 1 & $0,339 \%$ & $0,214 \%$ & $5,612 \%$ & $0,044 \%$ \\
\hline Quintile 2 & $0,196 \%$ & $0,131 \%$ & $2,820 \%$ & $0,031 \%$ \\
\hline Quintile 3 & $0,179 \%$ & $0,106 \%$ & $1,448 \%$ & $0,045 \%$ \\
\hline Quintile 4 & $0,119 \%$ & $0,083 \%$ & $0,764 \%$ & $0,058 \%$ \\
\hline Quintile 5 & $0,049 \%$ & $0,041 \%$ & $0,225 \%$ & $0,068 \%$ \\
\hline
\end{tabular}

Source: Own calculations. Data from IES 2005/2006, Statistics South Africa, 2008

Canned vegetables are currently the only sub-category of vegetables that is taxed. However, Table 3 shows distinctly different spending patterns between the income Quintiles across these four categories of vegetables. Quintile 1 spent the largest percentage $(0,339 \%)$ on canned vegetables, in contrast to Quintile 5 (which spent only $0,049 \%$ ). Similar findings are observed for frozen vegetables. The latter result is contrary to expectations, since it is often assumed that poor households own fewer or no refrigeration facilities; hence they are less likely to purchase frozen food. However, the IES 2005/2006 data reveal that 35,84\% of households in Quintile 1 own or have access to either a refrigerator or a freezer, which may explain the above-mentioned result. ${ }^{10}$ It is therefore likely that poorer households could also have consumed frozen vegetables. ${ }^{11}$

Spending on 'basic' fresh vegetables as a percentage of total income was $5.612 \%$ in Quintile 1, but only $0,225 \%$ in Quintile 5. In contrast, spending on 'other' fresh vegetables as a percentage of income increased across Quintiles $(0.044 \%$ and $0.068 \%$ for Quintile 1 and Quintile 5 respectively). Examples included broccoli, marrow and mushrooms (Refer to Table 2). ${ }^{12}$

In summary, these results suggest that canned, frozen and 'basic' fresh vegetables are relatively more essential in the food consumption basket of poor households, and ought to be considered for inclusion in the basket of zero-rated foodstuffs.

\subsection{Alternative targeting of zero-rating to enhance equity gains}

Considering the spending patterns identified in the previous section, it is crucial to investigate the impact of imposing VAT on the three vegetable sub-categories

\footnotetext{
$1040 \%$ of households in Quintile 1 resided in urban areas, which implies greater access to, and ownership of, refrigeration facilities.

11 Access to, and ownership of, refrigeration facilities do not necessarily explain relative spending patterns between income groups. One possible reason is relative price differences between vegetables and other food items.

12 The IES 2005/2006 does not provide a comprehensive list of all vegetables. It is therefore possible that other individual items may be identified on which poorer households spend a relatively smaller percentage of their income.
} 
(frozen, 'basic' and 'other' fresh vegetables) that are currently not taxed. The subsequent analyses follow a partial and static equilibrium approach ${ }^{13}$ since the focus is only on reducing the regressivity of VAT, while neither secondary effects nor price changes are considered. Conventional tax theory defines tax regressivity (or progressivity) in terms of the average tax rate. Rosen and Gayer (2008: 307) explain that if the average tax rate decreases (increases) with income, the tax is regressive (progressive). Johannes, Nju and Theresia (2006: 11) provide the following formula to calculate the tax payments for the different Quintiles. The tax paid is calculated as follows:

$\operatorname{Tax}=\left(\frac{\mathrm{t}}{1+\mathrm{t}}\right) \times \exp$

where

$\mathrm{t}=$ ad valorem tax rate, $\exp =$ amount of spending (inclusive of the VAT amount paid), as reported in IES 2005/2006. Using this formula the VAT (by income group) for different sub-categories of vegetables is determined. This is done to explore the possibility of improving the equity gain from the tax treatment of fresh vegetables, using the earlier distinction between 'basic' and 'other' fresh vegetables. Given that the rich spend disproportionately more on 'other' fresh vegetables than the poorest households, there is room for dividing food groups into sub-categories, which can be taxed differently in order to maximise the equity gain from zero-rating. Table 4 and Figure 1 show the results.

Table 4: VAT on different sub-categories of vegetables

\begin{tabular}{|c|c|c|c|c|}
\hline Category & $\begin{array}{c}\text { Canned } \\
\text { vegetables }\end{array}$ & $\begin{array}{c}\text { Frozen } \\
\text { vegetables }\end{array}$ & $\begin{array}{l}\text { 'Basic' fresh } \\
\text { vegetables }\end{array}$ & $\begin{array}{l}\text { 'Other' fresh } \\
\text { vegetables }\end{array}$ \\
\hline \multicolumn{5}{|c|}{ VAT amount (rand million, 2000 prices) } \\
\hline Quintile 1 & 7 & 5 & 139 & 1 \\
\hline Quintile 2 & 8 & 6 & 135 & 1 \\
\hline Quintile 3 & 12 & 8 & 118 & 3 \\
\hline Quintile 4 & 15 & 12 & 112 & 9 \\
\hline Quintile 5 & 26 & 24 & 135 & 41 \\
\hline \multicolumn{5}{|c|}{ VAT as percentage of income } \\
\hline Quintile 1 & $0,042 \%$ & $0,030 \%$ & $0,786 \%$ & $0,006 \%$ \\
\hline Quintile 2 & $0,024 \%$ & $0,018 \%$ & $0,395 \%$ & $0,004 \%$ \\
\hline Quintile 3 & $0,022 \%$ & $0,015 \%$ & $0,218 \%$ & $0,006 \%$ \\
\hline Quintile 4 & $0,015 \%$ & $0,012 \%$ & $0,107 \%$ & $0,008 \%$ \\
\hline Quintile 5 & $0,006 \%$ & $0,006 \%$ & $0,032 \%$ & $0,010 \%$ \\
\hline
\end{tabular}

Source: Own calculations. Data from IES 2005/2006, Statistics South Africa, 2008

\footnotetext{
13 According to Rosen and Gayer (2008:307), tax incidence analysis can be conducted using different techniques, for example, analysing the distributional impact of replacing one tax with another, while keeping tax revenue constant (referred to as differential tax incidence).
} 


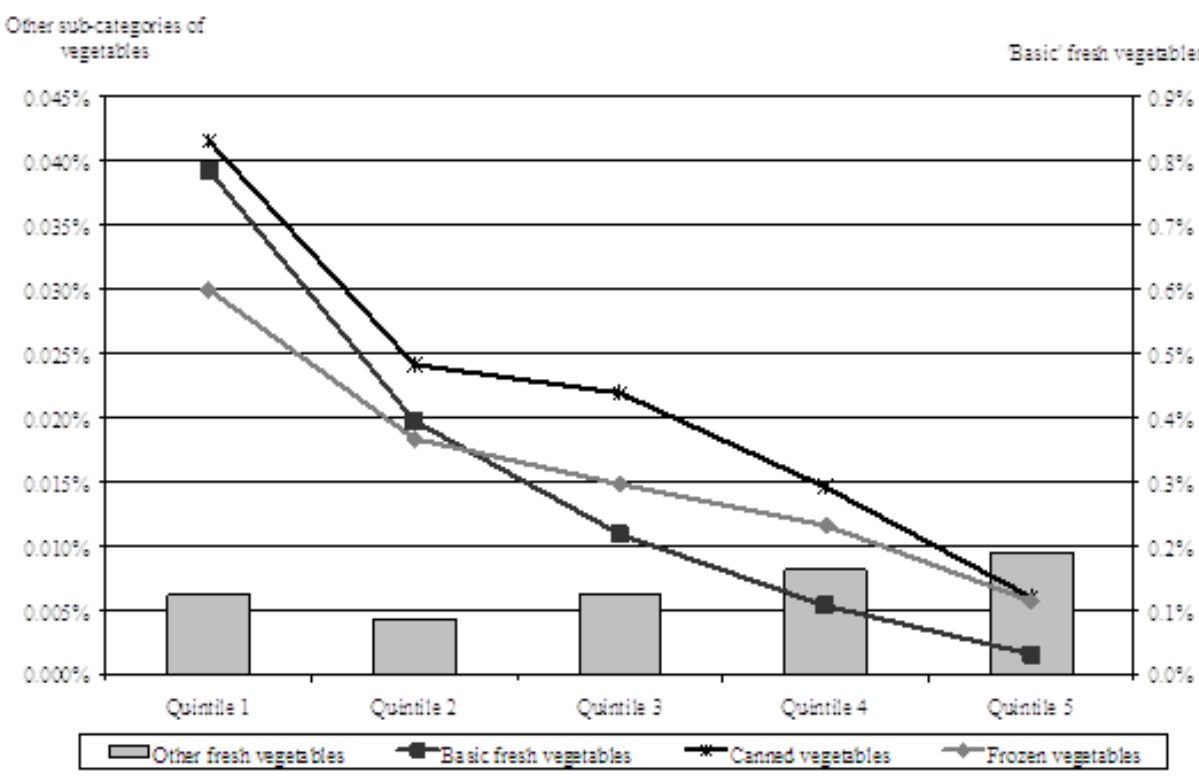

Source: Own calculations. Data from IES 2005/2006, Statistics South Africa, 2008.

Figure 1: VAT as percentage of income in each sub-category of vegetable items

Table 4 shows that the VAT paid (in absolute terms) increases across Quintiles in all sub-categories. The only exception is 'basic' fresh vegetables; households in Quintile 1 will pay R139 million in VAT, as compared to those in Quintile 5, who will pay R135 million. These results support the argument that 'basic' fresh vegetables should be included in the zero-rated basket.

VAT on canned vegetables as a percentage of income is regressive, i.e. the poorest households spend a greater percentage of their income on VAT. This implies that canned vegetables should be included in the zero-rated basket. It explains the rationale behind the earlier demands of the labour union federation (COSATU $1999)^{14}$ as well as the recommendations by Alderman and Del Ninno (1999). Alderman and Del Ninno (1999) also considered different taxing of sub-categories and proposed that canned vegetables should be zero-rated. This latter proposal was supported by COSATU (1999:3) in their submission to the Portfolio Committee on Finance, in which they suggested that "particular tinned foods which are consumed by low-income groups" and also claimed that the government's proposals were not based on "any study or statistical analysis of consumption patterns of the poor."

A comparison of the VAT currently paid on canned vegetables to the VAT households would be paying if zero-rating is removed from frozen vegetables involves making some assumptions about the price elasticity of demand for frozen vegetables. According to Alderman and Del Ninno (1999: 193), the price elasticity

14 Over the years COSATU has urged the government to ensure that VAT is not applied to basic foodstuffs. For example, in a submission to the Portfolio Committee on Finance, the union federation explicitly stated: "The absence of an effective social security system exacerbates the regressivity of VAT and strengthens the case for zero rating VAT on many basic goods and services." 
of demand for fruit and vegetables is $-0,82$. For this study it is thus assumed that the price elasticity of demand for vegetables is relatively inelastic. The relative price inelasticity of demand is one of the requirements if differentiated VAT rates are to be applied to sub-categories of food items (Cnossen 2003). Therefore, if prices were to increase due to the imposition of VAT, overall spending on frozen vegetables would increase, despite a decline in quantities bought. Since the price elasticity of demand is less than one (i.e. inelastic), an increase in price will lead to a smaller decrease in the quantity bought, which will increase total expenditure. Because of insufficient information on the price elasticity of demand for different items of vegetables, it is assumed that vegetable spending will remain unchanged in the event of price changes.

After imposing a rate of $14 \%$ on frozen vegetable spending, VAT paid as a percentage of income also shows a similar regressive pattern as in the case of canned vegetables. Table 4 shows that Quintile 1 would have paid $0,030 \%$ of their income, whereas Quintile 5 would have paid only $0,006 \%$. These results suggest that frozen vegetables should remain in the basket of zero-rated foodstuffs.

A comparison of the relative shares of VAT paid on canned and frozen vegetables indicates that VAT on canned vegetables is more regressive than it would be if VAT were to be applied to frozen vegetables. This finding has important implications for the zero-rating of VAT as it is currently applied to the vegetables food category. In the case of frozen vegetables, the analyses indicate that zerorating is well targeted, since the poor would pay a higher percentage of their income on VAT (should frozen vegetables be taxed at the standard rate $^{15}$ ). In contrast, however, the fact that canned vegetables are not zero-rated affects poor households relatively more than rich households; for Quintile 1, VAT paid as a percentage of income was higher in the case of canned vegetables. It therefore seems reasonable to propose that the zero-rating of VAT should be applied to canned vegetables.

Tait (1988:60) also supported the zero-rating of canned and frozen vegetables. In his exposition on the difficulty of distinguishing between processed and unprocessed food, he argued that even though it seems desirable from an equity and nutritional standpoint to zero-rate fresh food, it is more than likely that canned and frozen food would be bought by working women and factory workers. ${ }^{16}$

As mentioned earlier, fresh vegetables are currently zero-rated. To determine the economic incidence of VAT on fresh vegetables, a rate of $14 \%$ is applied to all items in these two sub-categories, on the assumption that total spending on fresh vegetables remains unchanged. Even though there is insufficient information on the

\footnotetext{
15 The calculations on the simulated VAT in the empirical analyses assume the standard rate of $14 \%$. Alternative specifications could have been considered in addition to this standard rate. However, given the concerns about a possible increase in the administrative burden, only two rates are adopted, namely $0 \%$ and $14 \%$.

${ }^{16}$ It should also be kept in mind that the South African tax authorities already apply zero-rating to canned fish (such as pilchards).
} 
price elasticities for individual items of fresh vegetables, given the existing empirical evidence of a relatively inelastic demand for the broad categories of fruit and vegetables, spending on fresh vegetables will not change significantly if prices were to increase. The VAT calculation is based on the (unchanged) existing spending patterns as identified using the IES 2005/2006 data.

With regard to the 'basic' fresh vegetables, Table 4 and Figure 1 show that VAT on these items would have accounted for $0.786 \%$ of income for Quintile 1, while it would have only been $0,032 \%$ for Quintile5. The regressive nature of VAT in this sub-category implies that zero-rating is accurately targeted. Considering the VAT on 'other' fresh vegetables as a percentage of income, the results contradict the findings of the other sub-categories. It would have been lower in Quintile 1 $(0.006 \%)$ compared to Quintile $5(0,010 \%)$, which reflects that the tax is progressive, i.e. the average tax rate increases as income increases. This strengthens the argument to remove zero-rating of VAT from selective 'other' fresh vegetables, whilst at the same time maintaining the policy of zero-rating 'basic' fresh vegetables.

Another method to compare the possible equity gains from zero-rating subcategories of food items is to calculate a weighted equity gain ratio, as suggested by Fourie and Owen (1993:294). Part of their analyses discussed optimal zero-rating of food items, "to maximise the gain to poor relative to rich households for a given revenue loss or tax expenditure". The weighting of the ratios reflects the greater importance of commodities to the poor. The higher the ratio for the specific food item, the greater the equity gains are for the poor. The ratio is calculated as follows:

\section{(Percentage of lowest income budget spent on good) squared}

Percentage of highest income budget spent on good

Table 5 shows the ratios for each sub-category of vegetables. ${ }^{17}$

Table 5: Weighted equity gain ratios on different sub-categories on vegetables

\begin{tabular}{l|c|c|c|c}
\hline Category & $\begin{array}{c}\text { Canned } \\
\text { vegetables }\end{array}$ & $\begin{array}{c}\text { Frozen } \\
\text { vegetables }\end{array}$ & $\begin{array}{c}\text { 'Basic' fresh } \\
\text { vegetables }\end{array}$ & $\begin{array}{c}\text { 'Other' fresh } \\
\text { vegetables }\end{array}$ \\
\hline $\begin{array}{l}\text { Weighted equity } \\
\text { gain ratio }\end{array}$ & 0,0234 & 0,0113 & 1,3988 & 0,0003 \\
\hline
\end{tabular}

Source: Own calculations. Data from IES 2005/2006, Statistics South Africa, 2008.

The ratio is the highest for 'basic' fresh vegetables $(1,3988)$, but the lowest for 'other' fresh vegetables $(0,0003)$. This result thus confirms the previous findings (refer to Table 4 and Figure 1) that 'basic' fresh vegetables are disproportionately consumed by the poor and should remain zero-rated. The ratio is the second highest for canned vegetables $(0,0234)$, suggesting that poorer households would gain should canned vegetables be included in the zero-rated basket.

\footnotetext{
${ }^{17}$ The second column of Table A.1 shows the weighted equity gain ratio for each vegetable item.
} 
Although not the focus of this paper, the suggested proposals have revenue implications. A rough estimate of the possible tax revenue impact is given as follows (see Table 6): if the absolute amounts of VAT paid on 'other' fresh vegetables are considered, households in Quintile 5 would have paid around R41 million per annum (as opposed to only R1 million by those in Quintile 1). In total, government revenue would have increased by approximately R55 million. Removing VAT from canned vegetables would, however, have resulted in a loss of tax revenue of R68 million in total, which implies a revenue loss of R13 (R68 R55) million. ${ }^{18}$ It should be kept in mind, though, that Quintile 1 would have paid R7 million less VAT on canned vegetables if VAT is zero-rated, as compared to R26 million for Quintile 5. Given the suggestions of zero-rating VAT on canned vegetables and taxing 'other' fresh vegetables, households in Quintile 1 would have paid R6 million less in terms of VAT, whereas those in Quintile 5 would have paid R15 million more. ${ }^{19}$

Table 6: Potential tax revenue effects (rand million, 2000 prices)

\begin{tabular}{l|c|c}
\hline Category & $\begin{array}{c}\text { Tax revenue lost by } \\
\text { removing VAT from canned } \\
\text { vegetables }\end{array}$ & $\begin{array}{c}\text { Tax revenue gained by } \\
\text { imposing VAT on 'Other' } \\
\text { fresh vegetables }\end{array}$ \\
\hline Quintile 1 & 7 & 1 \\
\hline Quintile 2 & 8 & 1 \\
\hline Quintile 3 & 12 & 3 \\
\hline Quintile 4 & 15 & 9 \\
\hline Quintile 5 & 26 & 41 \\
\hline
\end{tabular}

Source: Own calculations. Data from IES 2005/2006, Statistics South Africa, 2008.

\section{Conclusions and recommendations}

The zero-rating of VAT in South Africa, as well as the specific commodities that should be included in the zero-rated basket, is an issue that has been extensively researched over the years. The relative position of the poor is of the essence and it may be a price worth paying in a country with a Gini coefficient of 0,69 (Bhorat and Van der Westhuizen, 2012:8).

The main focus of this paper related to the question of whether zero-rating in South Africa is appropriately targeted. The paper accepts that zero-rating is not an optimal solution to the equity concerns of the tax, but that it is here to stay as part of a second-best solution, given the socio-political concerns. The study used the vegetable category as an example to illustrate that the targeting of zero-rated basic foodstuffs under VAT in South Africa could be improved.

\footnotetext{
18 The total tax revenue in the 2005/2006 fiscal year is R417 050 (National Treasury, 2006). Hence, the total net loss in absolute terms as a proportion of total tax revenue is R13 million / R417 050 million = $0,0031 \%$.

${ }^{19}$ These revenue estimates may be different depending on price elasticities.
} 
The study found expenditure patterns of different income groups as well as the incidence of VAT on vegetables as specific food category in South Africa. The findings were that it is possible to divide a specific food category (such as fresh vegetables) into the sub-groups of 'basic' and 'other', and that the spending patterns on the basic category are distinctively different between rich and poor. This opens the door for a policy recommendation to levy the standard VAT rate on 'other' fresh vegetables and to keep the zero rating only on the sub-category of 'basic' fresh vegetables.

The study also found that the zero-rating of frozen vegetables was well targeted as frozen vegetables were consumed relatively more by poorer households. However, it determined that the impact of VAT on canned vegetables was found to be more regressive than the possible impact should frozen vegetables be taxed. It is an anomaly that canned vegetables are still not zero-rated, despite earlier requests and the fact that it is a product disproportionately consumed by the relatively poorer households in the community. We therefore recommend that canned vegetables should be included in the zero-rated basket of basic foodstuffs. Some rough speculations on the tax revenue effects indicate a loss in revenue. However, in this case it is the poorest households that will benefit if these minor tax changes were to be implemented.

The findings of this study invite a more in-depth analysis of how appropriately zero-rating is applied to other food categories and suggest that such investigations must be done on a regular basis, as proposed by the Katz Commission (1994), since even small changes to the tax treatment as proposed in this paper may affect the relative position of the poorest households in South Africa. A related matter that policymakers should consider (as mentioned by various studies) is whether the intended benefit from zero-rating is really transferred to the end consumer and not absorbed earlier in the distribution chain. If the benefit does not reach the poorest households, zero-rating is a not an effective policy tool.

\section{References}

Alderman, H. \& Del Ninno, C. 1999. 'Poverty issues for zero rating value added tax (VAT) in South Africa'. South Africa: Poverty and inequality: Informal Discussion Paper Series 19336. Washington DC: World Bank.

Aaron, H.J. 1981. The value-added tax: Lessons from Europe. Washington DC: Brookings Institution.

Bhorat, H. \& Van der Westhuizen, C. 2012. 'Poverty, inequality and the nature of economic growth in South Africa.' DPRU Working Paper 12/151. Cape Town: Development Policy Research Unit, University of Cape Town.

Bird, R. 1992. Tax policy and economic development. Baltimore: John Hopkins University Press.

Bird, R. 2008. 'Tax challenges facing developing countries.' Institute for International Business Working Paper No 12. Toronto: Rotman School of Management, University of Toronto.

Calcaterra, M. \& Kirsten, J. 2003. An economic assessment of zero rating of VAT on red meat. Pretoria: University of Pretoria. 
Cnossen, S. 1991. 'Design of the value added tax: Lessons from experience'. In Khalilzadeh-Shirazi, J. \& Shah, A. (ed.). Tax policy in developing countries. A World Bank Symposium. Washington DC: World Bank: 72-85.

Cnossen, S. 2003. 'The incidence of consumption in member countries of the South Africa development community'. Paper prepared for the Southern African Conference on Excise Taxation, Centurion Lake Hotel, Gauteng, South Africa, 11-13 June 2003.

Cosatu. 1999. 'COSATU Submission on the Draft Revenue Laws Amendment Bill'. Presented to the Portfolio Committees on Finance, 17 September 1999. [online] URL: http://www.cosatu.org.za/show.php?ID=815 Accessed: 1 February 2009.

Ensor, L. 2008. 'VAT relief for the poor considered'. Business Day. 6 May 2008. [online] URL: http://www.businessday.co.za/Articles/Content.aspx?id=47271 Accessed: 26 November 2010.

Fourie, F. \& Owen, A. 1993. 'Value-added tax and regressivity in South Africa', South African Journal of Economics, 61(4): 308-319.

Gillingham, R. 2008. 'The distributional impacts of indirect tax and public pricing reforms: a review of methods and empirical evidence'. In Gillingham, R. (ed.). Poverty and social impact analysis by IMF: Review of methodology and selected evidence, 33-72. Washington DC: International Monetary Fund.

Go, D.S., Kearny, M., Robinson, S. \& Thierfelder, K. 2005. ‘An analysis of South Africa's value added tax’. World Bank Policy Research Working Paper 3671. Washington DC: World Bank.

Johannes, T., Nju, A. \& Theresia, A. 2006. 'The distribution of expenditure tax burden before and after tax reform: The case of Cameroon'. AERC Research Paper 161. Nairobi: African Economic Research Consortium.

Katz Commission. 1994. Interim report of the commission of inquiry into certain aspects of the tax structure of South Africa. Pretoria: Government Printer.

National Treasury 2006. 'National budget review 2005/2006'. Annexure B: Statistical Tables. [online] URL: http://www.treasury.gov.za/documents/national budget/2006/review/Annexure B.pdf Accessed: 27 June 2013

National Treasury \& South African Revenue Service. 2010. '2010 Tax statistics'. [online] URL: http://www.treasury.gov.za/publications/tax\%20statistics/2010/2010\%20Tax\%20Statistics.pdf Accessed: 13 July 2011

Nicholson, W. 1998. Microeconomic theory: Basic principles and extensions. 7th edition. Chicago: The Dryden Press.

Republic of South Africa. 2001. 'National budget review 2001'. Chapter 4: Revenue trends and tax proposals. Pretoria: National Treasury. [online] URL:

http://www.finance.gov.za/documents/national\%20budget/2001/review/Chapter\%204.pdf Accessed: 20 August 2008.

Republic of South Africa. 2008. 'Medium term budget policy statement 2008'. Pretoria: National Treasury. [online] URL:

http://www.treasury.gov.za/documents/mtbps/2008/default.aspx Accessed: 1 September 2009.

Rosen, H. \& Gayer, T. 2008. Public finance. 8th edition. New York: McGraw-Hill.

Smit, E.V.D.M. 1986. 'Die belastinglas van direkte en indirekte belastings op huishoudings in die RSA: 'n Beraamde verdeling tussen inkomsteklasse en rassegroepe'. Unpublished research report for the Margo Commission and Central Economic Advisory Service. 
Stoltz, E.A.P. 1987. "'n Vergelykende studie tussen die algemene verkoopsbelasting (AVB) in die SuidAfrikaanse belastingstelsel en ' $n$ toegevoegdewaardebelasting (BTW)'. M. Verhandeling. Stellenbosch: Universiteit van Stellenbosch.

Statistics South Africa. 2008. 'Income and expenditure survey 2005/2006'. Pretoria: Statistics South Africa.

Tait, A. 1985. Unpublished submission to the Department of Finance.

Tait, A. 1988. Value added tax. International practice and problems. Washington: International Monetary Fund.

Van der Berg, S. 2009. 'Fiscal incidence of social spending in South Africa, 2006'. Stellenbosch Economic Working Papers: 10/2009. Stellenbosch: Stellenbosch University. 


\section{Appendix}

Table A.1: Classification of vegetable items and the weighted equity gain ratio for each item

\begin{tabular}{|c|c|}
\hline Item & Weighted equity gain ratio \\
\hline \multicolumn{2}{|c|}{ Canned vegetables } \\
\hline Baked beans in tomato source & 0,035945 \\
\hline Tinned peas & 0,000749 \\
\hline Other canned vegetables & 0,000596 \\
\hline Butter beans & 0,000363 \\
\hline Canned green beans & 0,000310 \\
\hline Cream style sweet corn & 0,000061 \\
\hline Canned corn kernels & 0,000010 \\
\hline \multicolumn{2}{|c|}{ Frozen vegetables } \\
\hline Frozen pumpkin & 0,016663 \\
\hline Frozen potato chips & 0,013091 \\
\hline Frozen mixed vegetables & 0,000568 \\
\hline Frozen carrots & 0,000237 \\
\hline Frozen corn kernels & 0,000170 \\
\hline Other frozen vegetables & 0,000085 \\
\hline Frozen green beans & 0,000008 \\
\hline Frozen peas & 0,000007 \\
\hline Frozen cauliflower & 0,000000 \\
\hline \multicolumn{2}{|c|}{ 'Basic' fresh vegetables } \\
\hline Fresh cabbage & 0,792349 \\
\hline Potatoes & 0,724085 \\
\hline Fresh spinach/morogo & 0,545803 \\
\hline Fresh green mealies & 0,242357 \\
\hline Fresh tomatoes & 0,173047 \\
\hline Onions & 0,103889 \\
\hline Fresh pumpkin/butternut & 0,028718 \\
\hline Fresh mixed vegetables & 0,015169 \\
\hline Beetroot & 0,015019 \\
\hline Fresh carrots & 0,006204 \\
\hline Sweet potatoes & 0,003900 \\
\hline Fresh green beans & 0,002257 \\
\hline Fresh green/red/yellow pepper & 0,001992 \\
\hline Fresh chillies & 0,000385 \\
\hline \multicolumn{2}{|c|}{ 'Other' fresh vegetables } \\
\hline Lettuce & 0,000132 \\
\hline Fresh gem squashes & 0,000111 \\
\hline Fresh cauliflower & 0,000092 \\
\hline Fresh cucumber & 0,000079 \\
\hline Other fresh vegetables & 0,000008 \\
\hline Fresh broccoli & 0,000004 \\
\hline Mushrooms & 0,000003 \\
\hline Fresh marrow & 0,000002 \\
\hline
\end{tabular}

Source: Own calculations. Data from IES 2005/2006, Statistics South Africa, 2008. 